\title{
The Role of Agencification in the Post-2010 Financial Stabilization in Hungary
}

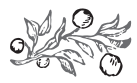

\section{Summary}

Agencification has had a major role in the institutional development and handling of the financial crisis in the European Union. In this article it is examined whether this institutional trend, along with the institutionalistapproach of Rodrik, has played asimilar rolein post-2010 financial stabilization in Hungary, and if so, exactly how it affected the process. The focus is on public administration, which was renewed on the Fundamental Law enacted in 2011, and providing a basis for the new legal and institutional framework for the regulation and supervision of the financial markets.

Journal of Economic Literature (JEL) codes: E02, E52, E58, G28, H63

Keywords: agencification, economic policy, European Union, financial supervision, Hungary, institutionalism, monetary policy

\section{INTRODUCTION}

Purpose

The trend called "agencification" is a well-known, few-decades old phenomenon in the organisational development of the regulatory and supervisory institutional system of the European Union and in its Member States and other countries like the USA or Latin-American countries.

Dr BÁlint Teleki, lawyer, PhD student, Department of European Public and Private Law, Faculty of International and European Studies, National University of Public Service (Teleki.Balint@uni-nke.hu). 
The purpose of this article is to examine the correlations and interactions between this trend and actions taken by the Hungarian government after 2010 in the interest of economic, especially financial stabilization. Following a general overview of the legal and institutional framework of financial regulation and supervision, and of monetary policy in the new public service system described in the new constitution (Fundamental Law, approved on 25 April 2011 and effective from 1 January 2012). Then the government policies and measures taken to consolidate state debt are discussed. General and Hungary-specific information is given on the doctrine of agencification in a separate chapter.

As a synthesis, the exact institutional pattern of financial regulation and supervision and monetary policy in Hungary are outlined and examined from the perspective of agencification, and from the perspective of the institutionalist doctrines of Rodrik.

\section{Methodology: Rodrik's institutionalist approach}

The post-2010 Hungarian government has intended to stabilize the economy of Hungary with measures resulting in systemic changes, by creating a new and consistent system of institutions and economic structures, instead of renewing a set of obsolete economic structures. These measures were rather unconventional from the viewpoint of the neoliberal economic dogmatics, and are therefore declared as "unorthodoxies" (Lentner, 2013, pp. 296-303). In this article the institutional changes of this process are to be examined, which requires a qualitative analysis (e.g. the analysis of the legal framework) rather than a quantitative analysis, apart from mentioning some simple and relevant figures. Hereunder is justified why exactly the approach of Rodrik is the best way to examine institutions. Further below, the examination from the aspect of the role of agencies and the trend of agencification will be presented as another institutionalist approach fitting very well into the paradigm of Rodrik.

In their research Dani Rodrik and Arvind Subramanian identified three "deep determinants" of income: geography, integration and institutions (see Figure 1) and found that the "quality of institutions overrides everything else" (Rodrik and Subramanian, 2003, p. 31). Institution is defined as by Lin and Nugent, quoted by Rodrik: "It is useful to think of institutions broadly as a set of humanly devised behavioural rules that govern and shape the interactions of human beings, in part by helping them to form expectations of what other people will do" (Lin and Nugent, 1995, pp. 2306-2307; Rodrik, 2000, p. 4). Rodrik adds: "All well-functioning market economies are 'embedded' in a set of non-market institutions, without which markets cannot perform adequately" (Rodrik, 2000, p. 4).

Rodrik distinguishes four types of institutions: 1) market creating institutions which protect property rights and ensure that contracts are enforced, 2) market regulating institutions which deal with externalities, economics of scale, and imperfect information, 3) market stabilizing institutions which ensure low inflation, minimize macro- 
economic volatility, and avert financial crisis, and 4) market legitimizing institutions which provide social protection and insurance, involve redistribution and manage conflict (Rodrik and Subramanian, 2003, p. 32; Lentner, 2013, pp. 28-29; Lentner, 2015, p. 24).

Figure 1: The three "deep determinants" of income by Rodrik

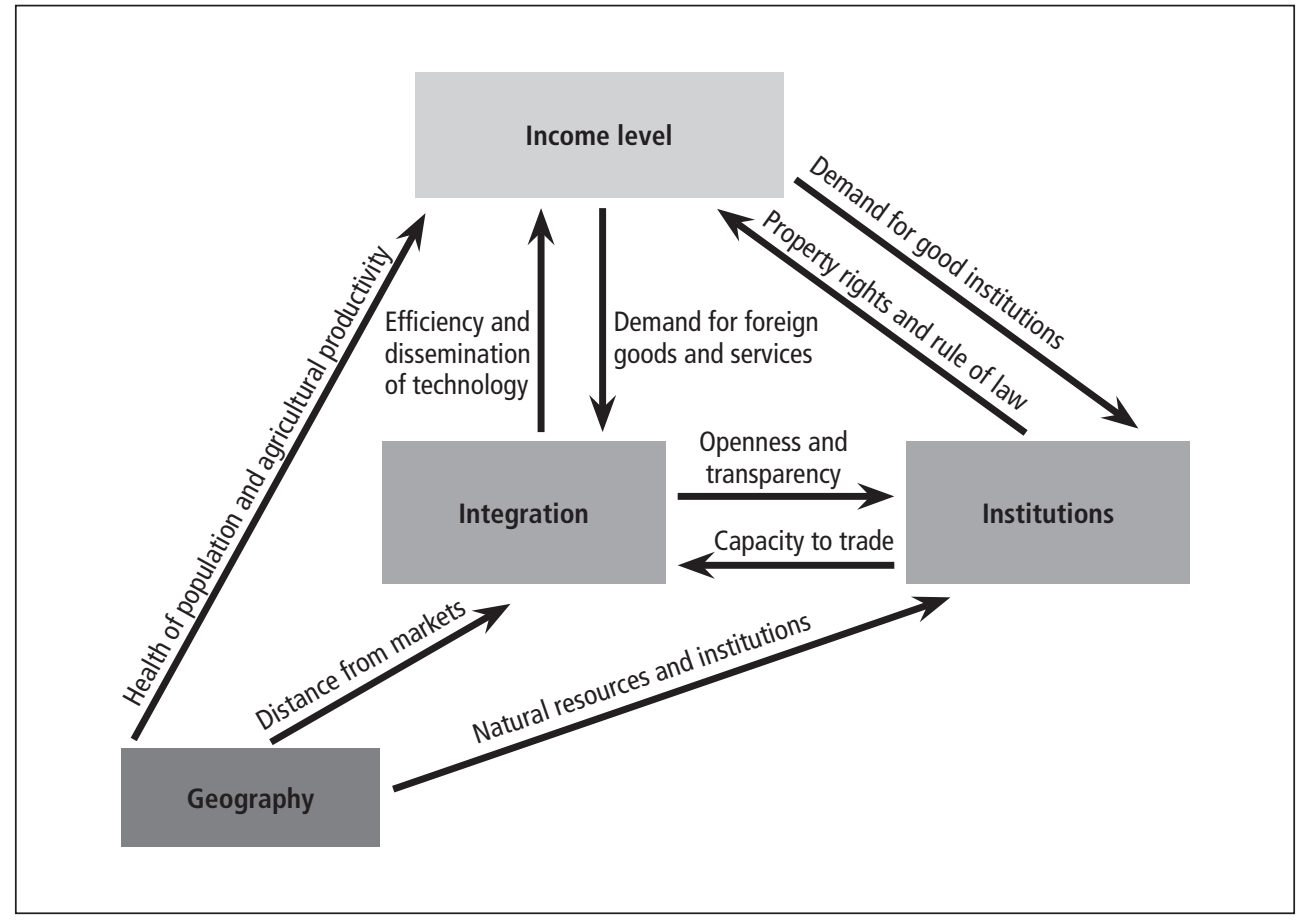

Source: Rodrik and Subramanian, 2003

There is an array of choices for all institutional functions. They include questions about the character of the legal regime, the balance between regulation and competition, the size of the public sector, etc. As a mere economic analysis cannot give answer to these questions, such country-specific factors as geography, history, political economy and other initial conditions influence the choice of forms. Rodrik emphasizes that "successful developing countries have almost always combined unorthodox elements with orthodox policies” (Rodrik and Subramanian, 2003, p. 33).

This is why Rodrik's institutionalist model is ideal for analysing the post-2010 economic policy and institutions of financial supervision in Hungary. Although Hungary is not a developing but a developed economy, its economic policy since 2010 has openly been declared (also in its self-definition) unorthodox and contrary to the neoliberal doctrines (Lentner, 2013, pp. 296-303), just as the paradigm of Rodrik, which was first declared unorthodox by the author himself, approximately a decade earlier than the April 2010 elections in Hungary (Rodrik, 2000, p. 3, 14). 
Bálint Teleki: The Role of Agencification in the Post-2010 Financial Stabilization...

ThE FINANCIAL STABILIZATION OF HUNGARY AFTER 2010

\section{The political context of financial stabilization}

The April 2010 (and then April 2014) parliamentary elections resulted in an overwhelming victory for the Fidesz-KDNP coalition, with a majority exceeding $2 / 3$ of the parliamentary seats, and this has enabled the coalition to change fundamental elements of the public and legal system, including the constitution. The previous constitution (Act XX of 1949) was affected by a communist heritage, since after the fall of the communist regime in 1989, no new constitution was adopted, only amendments were made in order to make the constitution comply with a capitalist democracy.

Numerous other elements of the legal system, in a number of legal fields from criminal to financial law, and especially in the field of administrative had been overamended over the decades, and therefore needed renewal or replacement. Other acts were enacted to fulfil the purposes of the economic policy of the government.

Another serious encumbrance was the heritage of the economic and financial crisis of 2007-2008. Besides the malfunctioning markets, the government had to struggle with the sovereign debt inherited from its predecessors, since the left-wing liberal coalition governing between 2002and 2010 hadactedaccording to the neoliberalidea that the state must be financed from international credits (IMF, World Bank and ECB) (see Lentner, 2013, pp. 317-322).

The crisis brought about a nearly global paradigm change. The neoliberal economic policy, and its administrative counterpart, the New Public Management (NPM) proved to be insufficient (Lórincz, 2010, pp. 50-51). NPM, focusing on competition and profit to measure the efficiency of administration in a given state, was replaced by the neo-Weberian State (NWS) (Lynn, 2008), a combination of "Weberian" and "neo" elements, in other words, a reorganisation of the Weberian elements without neglecting the achievements of the previous paradigms. Above all, this means "the reaffirmation of the state as the main facilitator of solutions to the new problems of globalization", the reaffirmation of representative democracy as legitimating element, the reaffirmation the role of administrative law in regard of the principles of state-citizen relationship, and "the preservation of the idea of a public service with distinctive status, culture, and terms and conditions" (Lynn, 2008, p. 27). The "neo" elements include e.g. the external orientation of the administration (i.e. towards citizens), the professionalization of public services, a redesign of the management of resources in order to focus on virtual achievements rather than simply following protocols, etc. (Lynn, 2008, p. 27).

The government policies adopted in 2010 closely follow these principles and apply economic unorthodoxy in order to fulfil the functions of the good state and good governance for the satisfaction of the citizens. Although in their study Domokos et al. mention that during the renewal of governance, the experiences gained in corporate management should be used, an intensive use of tools like the controls and reports by the State Audit Office of Hungary are inevitable for the good governance (Domokos et al., 2016). 


\section{Legal framework for financial supervision}

Besides the Fundamental Law, the most important legislative acts were those which redefined the administrative system in Hungary, including the institutional design and functional role of the organisations in charge of financial regulation and supervision.

The most comprehensive act regulating the institutional structure which second to the Fundamental Law in the hierarchy is Act XLIII of 2010 on central state administrative organisations and on the legal status of government members and state secretaries (Ksztv.). The Ksztv. defines the status and, in some cases, the competences of the certain types of administrative organisations. This categorization of the administrative organisations is crucial for our topic, since agencies, except for some, are certain types of organisations in this typology. (However, just as in most legal systems, under Hungarian law, "agency" is not defined in legal texts or not in the meaning or context it is used here. It has an administrative definition adjusted to legal requirements.)

The role of the Hungarian Financial Supervisory Authority (Pénzügyi Szervezetek Állami Felügyelete, PSZÁF) was re-regulated in Act CLVIII of 2010, in effect until the adoption of Act CXXXIX of 2013 on the National Bank of Hungary (Magyar Nemzeti Bank, $M N B$ ), which merged PSZÁF into the MNB. Financial institutions were also reregulated by the Act CCXXXVII of 2013 on Credit Institutions and Financial Enterprises and Act LXXXIII of 2014 on Business of Insurance.

Although fiscal legislation is beyond the scope of this article, two important acts have to be mentioned: Act CXCIV on the Economic Stability of Hungary and the Act LXVI of 2011 on the State Audit Office of Hungary, which, along with the relevant provisions of the Fundamental Law (mainly the chapter on Public Finances, i.e. Articles 36-44) unquestionably provide a restrictive safeguard against credit borrowings which would be contrary to the reasonable management of the state.

\section{Main achievements of the new economic policy of the Government of Hungary}

Below is a short overview on the structure of measures taken by the government to financially stabilize Hungary. The four main areas of the consolidation were: (1) the central state budget, (2) the social security system, (3) indebted municipalities, and (4) debtors indebted in foreign currency and the bank sector (Lentner, 2013).

The most serious problems of the central sub-system of the national budget included the growing budget deficit and sovereign debt. By extension of the scope of taxpayers, re-integration of private pension funds to the budget and launching programmes to reduce the unemployment rate and boost economic growth (such as the National Development Plan) the government managed to remedy the situation. As a result of the replacement of IMF loans by market-based ones, financial independence and Hungary's room to manoeuvre increased and exposure to IMF policies decreased (Lentner, 2013, pp. 322-323). The "supporting monetary policy" adopted by the MNB was a great assistance to the government. It is suffice to share two indices reflecting the achievements: the base interest rate of MNB fell from 7\% (in December 2011) to 
$2.1 \%$ (in September 2014), and since 2014 the inflation rate is around zero (Lentner, 2015, pp. 19-20).

The main point in the consolidation of the social security system included the re-integration of private pension funds. Indebted municipalities were consolidated in 2012 through both regulatory and bail-out measures. In order to assist people seriously indebted in foreign currency loans, regulatory measures were also introduced, such as the prohibition of unilateral contract amendments by banks, the fixed-rate consolidation of the loan amount into Hungarian currency, or the strengthened competences of the National Bank of Hungary and the then still existing Hungarian Financial Supervisory Authority (Lentner, 2013, pp. 324-329).

\section{AGENGIES WITH SPECIAL FOCUS ON FINANGIAL SUPERVISION}

\section{The nature of agencies}

There is no universal definition for the term "agency" and scholars cannot agree on a universal definition even in a single country (e.g. Hungary). The key elements include the non-departmental character and the relative independence of the central government. According to one of the most permissive definitions, agencies are non-departmental bodies, and in this approach, non-profit companies can also be agencies, provided that they have the required government background (since the definition says that an agency is an organisational unit created by acta iure imperii with a national competence under government control) with a considerably greater autonomy than ministerial departments, and a non-commercial purpose. Consequently, this definition only excludes for-profit companies (Hajnal, 2011, pp. 57-59).

According to another definition, in a functionalist approach, three activities must be performed by an organisation to qualify as an agency: 1) adoption of decisions as an authority, and give guidance to other participants in the given market, 2) functioning as a quasi-court, with a board making decisions in adversarial procedures and 3) functioning as a quasi-legislator, creating mostly soft laws (Fazekas, 2013, pp. 111112). The latter definition, especially the first condition, emphasizes another important characteristic of agencies, namely that they are almost always bound to a special type of market, sector or policy.

In addition, the latter definition clearly shows that, irrespective of their specific sector, agencies meet the conditions of market creating institutions since they enforce certain rights. They also meet the conditions of market legitimizing institutions, as for instance manage and resolve conflicts.

The phenomenon called agencification has a double meaning in the relevant literature. On the one hand, it means the quantitative proliferation of agencies under a certain legal regime, and on the other, it represents qualitative changes: agencies are assigned an increasing number of tasks, and consequently, new competences to perform these tasks. This trend is closely related to the paradigm of new statism discussed above. 


\section{The agencies of the European Union}

\section{The EU agencies in general}

Although the history of agencies is considered to begin in the Pan-American continent at around the middle of the 20th century (Kálmán, 2013, p. 1), the European Union has a long history of agencies, with an increasingly intense trend of agencification in approximately the last three decades.

The EU-specific agency-definition, accepted in this study due to its consistency, is as follows: "A 'European agency' is a public administration body established by a legal act of the European Union, has a legal personality and a relatively independent organisation, and participates in the regulation of a certain line on a European level and/or in the implementation of a EU-policy" (Kálmán, 2013, p. 3).

The above definition reflects the most controversial features of agencies, namely, their relative independence and non-departmental character. By nature, EU agencies are non-treaty based, which means that they do not have an explicit legal basis in the primary law of the EU (Szegedi, 2012, p. 349). They are only implicitly acknowledged in the Founding Treaties, and Art. 263 (1) and (5) of the Treaty on the Functioning of European Union (TFEU) provides a legal remedy against the decisions of agencies, when it talks about "bodies, offices and agencies" of the European Union as objects of legal control of the Court of Justice of the European Union (CJEU).

To understand the exact place and role of the agencies in the $\mathrm{EU}$, the structure of the European administration need to be considered briefly. Danwitz distinguishes the EU's own administrative law (Eigenverwaltungsrecht), enforced by the organisations of the EU, the common administrative law (Gemeinschaftsverwaltungsrecht), enforced by the authorities of the Member States, and cooperative administrative law (Kooperations- oder Verbundverwaltungsrecht), enforced in cooperation (Danwitz, 2008, pp. 312314). Since agencies are subject to the EU's own administrative law (Danwitz, 2008, p. 319), as a result of agencification, the enforcement of the EU law shifts towards direct enforcement, which means that the positions of EU organisations are strengthening in comparison to the authorities of Member States.

In this article Comte's functional categorization is adopted with five types of EU agencies: 1) decision-making agencies (e.g. the European Union Intellectual Property Office, which is the successor of the former Office for Harmonisation in the Internal Market), 2) agencies providing direct assistance to the Commission and, where necessary, to the Member States, in the form of technical or scientific advice and/or inspection reports (e.g. European Maritime Safety Agency), 3) agencies in charge of operation activities (e.g. EUROPOL), 4) information agencies (e.g. European Centre for the Development of Vocational Training) and 5) agencies providing services to other agencies and institutions (e.g. Translation Centre for the Bodies of the European Union) (Comte, 2010, pp. 84-86).

Chronologically, three generations are distinguished: 1) first-generation agencies, established before 1975, 2) second-generation agencies, established between 1975 and 
the 2003 framework regulation and 3) third-generation agencies, including executive agencies set up in accordance with the framework regulation (Council Regulation (EC) No 58/2003 of 19 December 2002 laying down the statute for executive agencies to be entrusted with certain tasks in the management of Community programmes) and the regulatory agencies created after 2003 (Danwitz, 2008, pp. 319-320).

This leads us to the third important categorization including a difference between executive and regulatory agencies. According to the relevant communication of the Commission, executive agencies were created in accordance with and on the basis of the abovementioned framework regulation (European Commission, 2008, p. 3). The regulatory agencies have their own separate legal bases, which are generally separate regulations for each of them.

\section{The European Supervisory Authority}

The three financial supervisory authorities, namely, the European Banking Authority (EBA), the European Securities and Markets Authority (EMSA) and the European Insurance and Occupational Pensions Authority (EIOPA), collectively referred to as European Supervisory Authorities (ESA) are third-generation decision-making

\section{Figure 2: The European Supervisory Authorities in the European System of Financial} Supervision

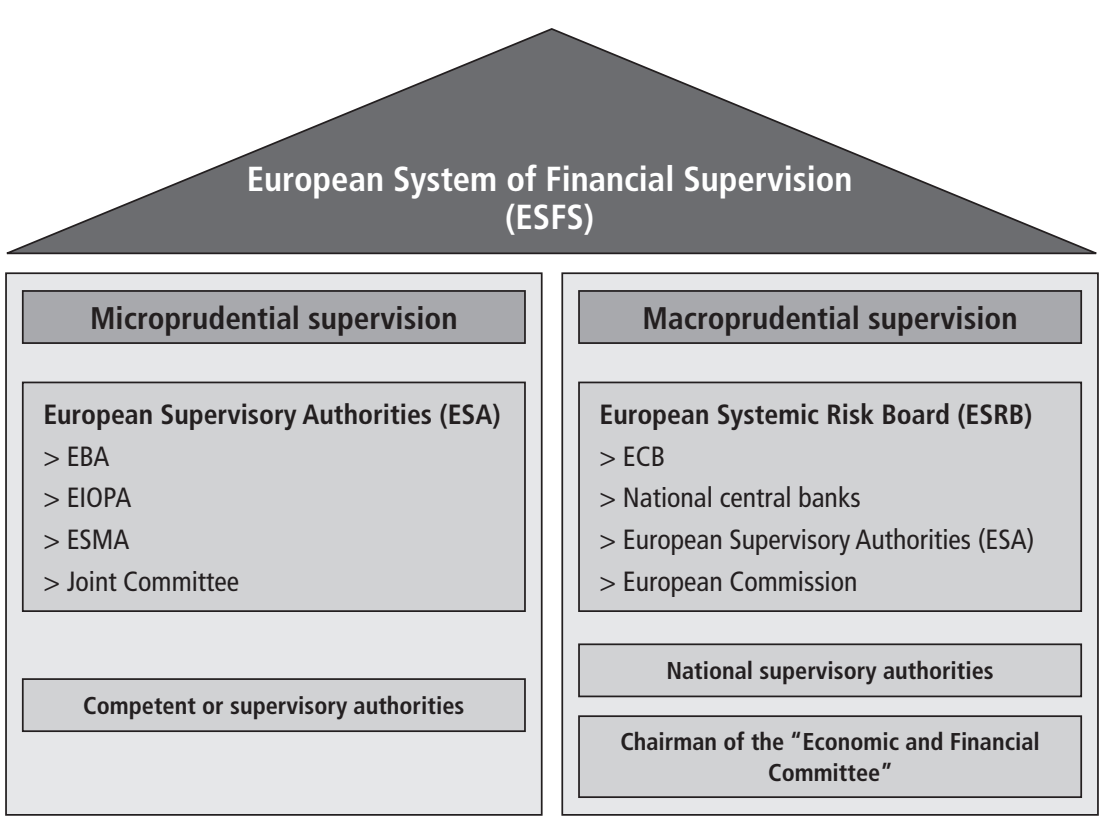

Source: Commission de Surveillance du Secteur Financier, Luxembourg, www.cssf.lu/en/eu-international/eu-authorities/ 
regulatory agencies. These three agencies were established after several unsuccessful efforts made by the decision-makers of the EU to handle the 2007-2008 crisis, when they realized that more powerful organisations are needed to regulate and supervise the three sub-sectors of the financial market. On the one hand, this decision is a welcome acknowledgment of the failure of the concept of the neoliberal self-regulatory market, and on the other, the extensive competences of these authorities may seem to be an overkill or a legal risk for the participants of the market.

Given that these agencies are beyond the focus of this article, only the highest risk is mentioned here: Art. 8 (2) f) of each of the three statutes (1092/2013/EU, 1094/2010/ EU and 1095/2010/EU regulations establishing the European Supervisory Authorities), which enables the agencies to make individual decisions addressed to financial institutions in specific cases, practically bypassing Competent National Authorities.

Although the three ESAs have a common Board of Appeal to provide legal remedy against such decisions, and clients can also appeal to the CJEU against the decision of the Board of Appeal, as Cleynenbreugel points out, several questions still remain: e.g. it is not clear whether the Competent National Authorities and the respective Member States can take a different stance in the case, and what types of decisions the client can appeal (for further details see Cleynenbreugel, 2012, pp. 242-249).

\section{Agencies in Hungary in after 2010}

Agencies cannot be mentioned in Hungary before the 1989-1990 end of the communist regime, because the term cannot be interpreted in an authoritarian regime. This article only focuses on Hungarian public service agencies set up by Parliament elected in April 2010 (and the Government in office after June 2010).

In the new public service system of Hungary, in the opinion of the author of this article, "autonomous regulatory organisations" (as defined in Art. 23 of the Fundamental Law, and Art. 1 (6) Ksztv.) qualify primarily as agencies. This is decided, however, by the science of administration rather than legal acts, since the Hungarian legal system, similarly to other legal systems in Europe does not use the term "agency".

According to the Fundamental Law: "Parliament may establish autonomous regulatory organs by a cardinal Act for the performance of certain tasks and the exercise of certain competences belonging to the executive branch" (Art. 23 (1) Fundamental Law) and "The head of an autonomous regulatory organ shall be appointed by the Prime Minister or, on the proposal of the Prime Minister, by the President of the Republic for the term specified in a cardinal Act. The head of an autonomous regulatory organ shall appoint his or her deputy or deputies" (Art. 23 (2) of the Fundamental Law). "The head of an autonomous regulatory organ shall report annually to Parliament on the activities of the autonomous regulatory organ" (Art. 23 (3) of the Fundamental Law). "Acting on the basis of authorisation by an Act and within his or her functions laid down in a cardinal Act, the head of an autonomous regulatory organisation shall issue decrees; no such decree shall conflict with any Act, government decree, decree of the Prime Minister, decree of a Minister or decree of the Governor of the National Bank of Hungary. In is- 
suing decrees, the head of an autonomous regulatory organisation may be deputized by the deputy appointed in a decree" (Art. 23 (4) of the Fundamental Law).

The above quoted provisions of the Fundamental Law clearly show that autonomous regulatory organisations have a distinct position in the public administration of Hungary in comparison to other organisation types listed in the Ksztv. First of all, the other types are not regulated in a separate article, or a special regulation in the Fundamental Law, which means that the legislator does not deem it necessary to regulate them on constitutional level, and consequently, their function does not require constitutional guarantees to balance the power of executive organisations. Moreover, as revealed in Art. 23 (4), the decree issued by the head of an autonomous regulatory organisation is a normative act, as it is included in the hierarchy of normative legal acts. It follows from this that autonomous regulatory organisations are not only quasilegislators, but in the executive branch it is authorised to regulate by normative acts.

According to Art. 1 (6) of the Ksztv., only two organisations qualify as autonomous regulatory organisations: the Hungarian National Media and Infocommunications Authority (Nemzeti Média- és Hirközlési Hatóság, NMHH) and the Hungarian Energy and Public Utility Regulatory Authority (Magyar Energetikai és Közmú-szabályozási Hivatal, MEKH). Before its merger into the National Bank of Hungary (MNB) on 1 October 2013, the third one was the Hungarian Financial Supervisory Authority.

The acts establishing and defining the duties of NMHH and MEKH assign them the competences of an authority and the powers of a quasi-court. (In the case of NMHH, these acts include Act CLXXXV of 2010 on the Media and Act C of 2003 on Electronic Communications, while MEKH is subject to Act XXII of 2013 on the Hungarian Energy and Public Utility Regulatory Authority). For example, Art. 165 (1) of the Media Act allows clients to appeal against NMHH's decisions adopted as an authority to its supervisory organ, the Media Council. These organisations also issue soft-law documents.

In conclusion it can be said that both NMHH and MEKH fit in the above definition given by Fazekas, since they function as authorities, quasi-courts and quasi-legislators. In the author's opinion, there is no other organisation type which would meet all these criteria in general. The National Bank of Hungary, which is not regulated by the Ksztv. but by a separate act, the already mentioned MNB Act, can be considered as an agency, in the next chapter this statement will be justified.

THE NEW HUNGARIAN SYSTEM OF FINANGIAL SUPERVISION Transitional period between the Act on PSZÁF (2010) and the new MNB Act (2013)

General ideas about the system

In this period, there was a joint financial supervision depending on the institutional cooperation between PSZÁF, the MNB, the Hungarian Competition Authority (Gazdasági Versenyhivatal, GVH), the three European Supervisory Authorities established in the meantime, and other specific (or sometimes general, e.g. European Commis- 
sion) organisations on both a EU and a national level (Seregdi, 2013; Sudár, 2013). The MNB (which was at that time regulated by the short-lived Act CCVIII of 2011) was primarily responsible for monetary policy and the macroprudential supervision of financial markets, while PSZÁF was responsible for microprudential supervision.

As Art. 41 (1) of the Fundamental Law stipulates: "The National Bank of Hungary shall be the central bank of Hungary. The National Bank of Hungary shall be responsible for monetary policy as laid down in a cardinal Act." As Art. 3 of the MNB Act provides: "The primary objective of the MNB shall be to achieve and maintain price stability. Without prejudice to the primary objective, the MNB shall support the maintenance of the stability of the system of financial intermediation, the enhancement of its resilience, its sustainable contribution to economic growth; furthermore, the MNB shall support the economic policy of the government using the instruments at its disposal."

The above provisions stipulate that the primary objective of the MNB is to ensure price stability: "The MNB shall define and implement monetary policy" (Art. 4 (1) of the MNB Act), and in addition, it is required to support the stability of the financial market and the fiscal policy of the government.

Figure 3: The Hungarian agencies in after 2010; the development of the financial supervision

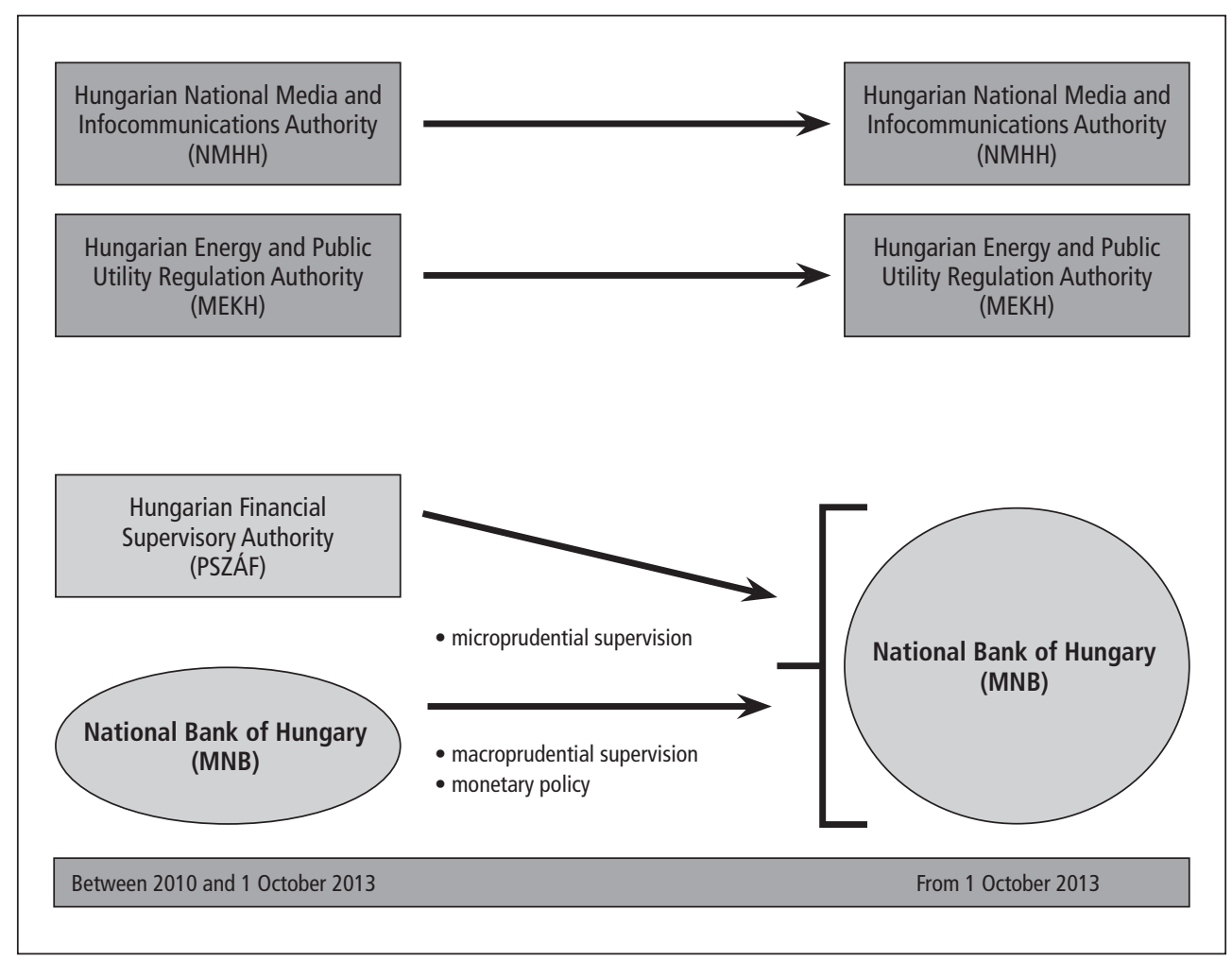

Source: Edited by the author 
The interval discussed here followed the first regulatory responses of the European Union to the financial-economic crisis of 2007-2008, and consequently, the European Supervisory Authorities established by the European Systemic Risk Board (ESRB) already had a key role in prevention of system risks. The three ESAs, the ESRB and other minor organisations jointly constitute the European System of Financial Supervision (ESFS), with the national central banks acting as Member State-level macroprudential supervisors (Szombati, 2013, pp. 139-143).

Support to the government's fiscal policy is tantamount to promoting the maintenance of price stability, i.e. efforts to cut inflation. It is implemented using instruments such as the Funding for Growth Scheme (Növekedési Hitelprogram, NHP), launched in the in the spring of 2013 and intended to assist SMEs in their credit strategies by granting credits for investments and through current asset financing (Pillar I), credit management (Pillar II), both under favourable conditions; while Pillar III of the NHP is a special foreign currency interest rate swap aimed at providing euro-liquidity, also under favourable conditions (Lentner, 2013, pp. 202-208).

As mentioned above, up to the merger on 1 November 2013, PSZÁF was required to focus on the microprudential supervision of the financial market and institutions. Its competences fall into seven categories: 1) licensing: the operation or mergers of financial and credit institutions, 2) supervision: the classic duty with strong investigative powers, 3) law enforcement: taking individual measures in specific cases, 4) regulation: active cooperation with the legislator in the development of the regulatory environment, 5) consumer protection: strong licences and innovative solutions (see below), 6) acting as a market authority: protecting the market mainly by prohibitions and, in criminal cases, by reports to the relevant authorities and 7) the publication of recommendations: communication to all market participants regarding expectations, supervisory experiences etc. in the form of soft-law documents (Seregdi, 2013, pp. 409-414).

Regarding consumer protection, it should be emphasized that perhaps the most important actor in Hungarian financial consumer protection, the Financial Arbitration Board (Pénzügyi Békéltetố Testület, PBT) started operation on 1 January 2011. It is engaged in conflict management and mediation and is a key element in consumer protection in Hungary (Czajlik et al., 2013, pp. 444-445).

System assessment - in terms of agencification

Before 2010, PSZÁF had various organisational forms, changed within almost every three years, was definitely an autonomous regulatory organisation under Art. 1 (6) b) of the Ksztv. Taking into consideration the statements made in the relevant chapter, it qualifies as an agency. Against the conditions set up by Fazekas, PSZÁF: 1) was definitely and, by definition, an authority, 2) functioned as a quasi-court (e.g. the PBT) and 3) functioned as a quasi-legislator, since in addition to issuing soft-law documents for the market it supervised, it also acted as an autonomous regulatory organisation with authorisation based on the Fundamental Law to issue decrees included in the regular hierarchy of normative acts. 
The MNB, in the author's opinion, did not qualify as an agency in that period. First of all, regarding its form, the MNB has never belonged to any type of organisations listed in the effective Ksztv. or other statutory regulations other than the MNB Act, which provides that it is "a legal person functioning in the form of company limited by shares", with shares in the Hungarian state's exclusive ownership (Art. 5 of the MNB Act). As it is definitely not a non-profit company, but deals with profits and losses, and according to the definition of Hajnal, it should be excluded from the category of agencies. According to the definition given by Fazekas, it also fails the test, because although it functioned as an authority and as a quasi-legislator in terms of its macroprudential competences, it is definitely not a quasi-court.

System assessment in Rodrik's institutionalist approach

Both PSZÁF and the MNB contributed a great deal to the stability of the financial system of Hungary. In the author's opinion, both embody all four institutional categories described by Rodrik.

Their enforcement functions regarding the financial market and its participants make them market creating institutions. On account of their objectives and competences they clearly qualify as market regulating institutions. The fact that both were established with the purpose of protecting market stability (PSZÁF on a microprudential and the MNB on a macroprudential level) makes them market stabilizing institutions. Finally, as the MNB is involved in re-distribution (see NHP) and PSZÁF was engaged in conflict management (see PBT), both of them are market legitimizing institutions.

\section{The financial supervisory system after 1 October, 2013}

In accordance with the provisions of the new MNB Act, PSZÁF ceased to exist as an independent organisation and merged into the MNB with effect from 1 October, 2013. The MNB has taken over the objectives and competences of PSZÁF with immediate effect upon the merger. For our purposes this means that according to Fazekas's definition of "agency", the MNB qualifies as an agency. In terms of the institutional model, the MNB embodies all four institutional categories.

\section{CONGLUSiONS}

The role of institutions in sustaining a well-functioning market economy is unquestionable. Long before the latest financial-economic crisis of 2007-08, at around the millennium, Rodrik and Subramanian designed a model of institutions whose presence is a prerequisite to the successful functioning of such an economy. In parallel, another institutional trend called agencification is gaining increasing significance in the European Union. These two institutionalist approaches are unavoidable in the examination of the responses given by a government of any Member State of the European Union, in this case Hungary. 
In conclusion, it can be established that after 2010, the government of Hungary has definitely managed to keep pace with the above-mentioned institutional trends and make the administrative system comply with the expectations of the European Union.

Regarding economic policies, however, the government of Hungary decided to take a different path than expected of us by the EU, which, up to now, has proved to be a great success, and hopefully will continue to do so. The Hungarian government decided to give up the neoliberal ideas, the New Public Management, and the debt management relying on credits from the IMF and the World Bank.

Unorthodox measures were introduced instead, and the role of the state and administration in the regulation and supervision of the economy was replaced by a neoWeberian one. The IMF-credit was paid off and the financial exposure of the country was radically decreased. Economy boosting programmes were launched and the MNB supports the fiscal steps of the government by monetary policy instruments.

The financial market, perhaps the most seriously hit by the crisis, was gradually brought under a strong and responsive regime of regulation and supervision, which seems to function correctly. Disregarding the fact that the financial environment changes rapidly, the MNB became a powerful key stakeholder that qualifies as an agency, represents all four ideal institution types set out by Rodrik, and successfully manages both monetary policy and the macro- and microprudential supervision of the financial markets and its participants.

To sum it up: agencification has definitely played a major role in, and had a substantial effect on, the development of post-2010 financial stabilization in Hungary.

\section{REFERENCES}

Czajlik, István; Horváth, Anna and Sz. Pap, Judit (2013): Korszerú pénzügyi fogyasztóvédelem [Contemporary financial consumer protection]. In: Lentner, Csaba (ed.): Bankmenedzsment. Bankszabályozás, pénzügyi fogyasztóvédelem [Bank management: bank regulation, financial consumer protection]. Nemzeti Közszolgálati és Tankönyvkiadó, Budapest, pp. 431-464.

Cleynenbreugel, Pieter van (2012): Judicial Protection Against EU Financial Supervisory Authorities in the Wake of the Regulatory Reform. ELSA Malta Law Review, Vol. 2, pp. 231-263.

Comte, Françoise (2010): 2008 Commission Communication 'European Agencies - the Way Forward': What is the Follow-Up Since Then? Review of European and Administrative Law, Vol. 3, No. 1, pp. 65-110, https://doi.org/10.7590/real_2010_01_04.

Danwitz, Thomas von (2008) Europäisches Verwaltungsrecht. Springer-Verlag, Berlin-Heidelberg.

Domokos, László; Várpalotai, Viktor; Jakovác, Katalin; Németh, Erzsébet; Makkai, Mária and Horváth, Margit (2016): Renewal of Public Management. Contributions of State Audit Office of Hungary to Enhance Corporate Governance of State-Owned Enterprises. Public Finance Quarterly, Vol. 61, No. 2, pp. 178-198.

European Commission (2008): European Agencies - The Way Forward. COM(2008) 135 final, Brussels, 11 March.

Fazekas, János (2013): Szabályozó hatóságok és önálló szabályozó szervek Magyarországon [Regulatory authorities and autonomous regulatory organisations in Hungary]. In: Fazekas, Marianna (ed.): $U_{j} j e^{-}$ neráció a közigazgatástudományok múvelésében [New generation in the praxis of administrative science]. Conference lectures, ELTE-ÁJK, Budapest, pp. 103-116.

Griller, Stefan and Orator, Andreas (2010): Everything under Control? The "Way Forward" for European Agencies in the Footsteps of the Meroni-doctrine. European Law Review, Vol. 35, No. 1, pp. 3-35. 


\section{Civic Review · Vol. 14, Special Issue, 2018}

Hajnal, György (2011): Adminisztratív politika a 2000-es évtizedben. Az ügynökség-típusú államigazgatási szervek strukturális dinamikája 2002 és 2009 között [Administrative policies in the decade 2000s: the structural dynamics of the agency-type administrative organisations between 2002 and 2009]. Politikatudományi Szemle, Vol. 20, No. 3, pp. 54-74.

Hofmann, Herwig C. H. and Morini, Alessandro (2012): Constitutional Aspects of the Pluralisation of the EU Executive Through “Agencification”. University of Luxembourg Law Working Paper, No. 1, pp. 1-41, http://dx.doi.org/10.2139/ssrn.2031499.

Kálmán, János (2013): Az európai ügynökségek és a Meroni-doktrína [The European agencies and the Meroni doctrine]. De iurisprudentia et iure publico, Vol. 7, No. 3, pp. 1-17.

Lentner, Csaba (2013): Közpénzügyek és államháztartástan [Public finance and study of the general government]. Nemzeti Közszolgálati Egyetem, Budapest.

Lentner, Csaba (2015): Szemelvények a regnáló magyar közpénzügyi rendszerrôl - intézményi és nemzeti történeti háttérrel [Excerpts from the reigning Hungarian public finance system with institutional and national historical background]. In: Kálmán, János (ed.): Állam, válság, pénzügyek [State, crisis, finances]. Batthyány Lajos Szakkollégiumért Alapítvány, Gyôr, pp. 11-51.

Lentner, Csaba (2016): A gazdasági válság hatása a globális, uniós és hazai szabályozási környezetre, különös tekintettel a felügyeleti elvekre [The effect of the economic crisis on the global, EU-level and national regulatory environment with special outlook to the supervising organisations]. In: Auer, Ádám and Papp, Tekla (eds.): A gazdasági világválság hatása egyes jogintézményekre Magyarországon és az Európai Unióban [The effect of the global economic crisis on certain legal institutions in Hungary and the European Union]. Nemzeti Közszolgálati Egyetem, Budapest, pp. 45-84.

Lentner, Csaba and Zéman, Zoltán (2017): A pénzügyi válság bankszabályozási controll elveinek meghatározóbb történeti elemei [The most determinative historical elements of the control principles of bank regulation of the financial crisis]. Európai Jog, Vol. 17, No. 1, pp. 8-13.

Lin, Justin Yifu and Nugent, Jeffrey B. (1995): Institutions and Economic Development. In: Behrman, Jere and Srinivasan, T. N. (eds.): Handbook of Development Economics, Vol. 3A. North-Holland, Amsterdam, https://doi.org/10.1016/s1573-4471(05)80010-5.

Lốrincz, Lajos (2010): A közigazgatás alapintézményei [Fundamental institutions of the public administration]. HVG-ORAC, Budapest.

Lynn, Laurence E. (2008): What is a Neo-Weberian State? Reflections on a Concept and Its Implications. NISPAcee Journal of Public Administration and Policy, Vol. 1, No. 2, pp. 17-30.

Rodrik, Dani (2000): Trade policy reform as institutional reform. Harvard University, August 2000, www.sss.ias. edu/files/pdfs/Rodrik/Research/trade-policy-reform-institutional-reform.PDF (accessed 5 November 2017).

Rodrik, Dani and Subramanian, Arvind (2003): The Primacy of Institutions (and What This Does and Does Not Mean). Finance and Development, Vol. 40, No. 6, pp. 31-34, www.imf.org/external/pubs/ft/ fandd/2003/06/pdf/rodrik.pdf (accessed 5 November 2017).

Seregdi, László (2013): A PSZÁF jelenlegi helyzete, szerepe, a várható, illetve az indokolt változások [The current situation and role of the HSFA, and the reasonable and expectable changes in it]. In: Lentner, Csaba (ed.): Bankmenedzsment. Bankszabályozás, pénzügyi fogyasztóvédelem [Bank management: bank regulation, financial consumer protection]. Nemzeti Közszolgálati és Tankönyvkiadó, Budapest, pp. 401-430.

Sudár, Gábor (2013): A tôkepiaci szolgáltatások szabályozása [The regulation of the services on the securities market]. In: Lentner, Csaba (ed.): Bankmenedzsment. Bankszabályozás, pénzügyi fogyasztóvédelem [Bank management: bank regulation, financial consumer protection]. Nemzeti Közszolgálati és Tankönyvkiadó, Budapest, pp. 319-364.

Szegedi, László (2012): Challenges of Direct European Supervision of Financial Markets. Public Finances Quarterly, Vol. 57, No. 3, pp. 347-357.

Szombati, Anikó (2013): A makroprudenciális felügyeleti hatáskör Magyarországon [The macroprudential supervisory competences in Hungary]. In: Lentner, Csaba (ed.): Bankmenedzsment. Bankszabályozás, pénzügyi fogyasztóvédelem [Bank management: bank regulation, financial consumer protection]. Nemzeti Közszolgálati és Tankönyvkiadó, Budapest, pp. 127-176. 